УДК 373.3

DOI:

Олег Довгий, кандидат фізико-математичних наук, доцент, дочент кафедри педагогіки початкової освіти

Прикарпатського національного університету імені Василя Стефаника

Марія Копчук-Кашецька, кандидат педагогічних наук, доцент, дочент кафедри педагогіки початкової освіти Прикарпатського національного університету імені Василя Стефаника

\title{
РОЗВИТОК ТВОРЧИХ ЗДІБНОСТЕЙ УЧНІВ ПОЧАТКОВОЇ ШКОЛИ ЯК АКТУАЛЬНЕ ЗАВДАННЯ СУЧАСНОЇ УКРАЇНСЬКОЇ ШКОЛИ
}

Стаття присвячена проблемі розвитку творчих здібностей учнів початкової школи. Чинні освітні документи спрямовують на формування всебічно розвиненої особистості. Важливе місие в цьому процесі науковиі, освітяни відводять проблемам творчого розвитку особистості молодшого школяра, оскільки саме в иьвому віці закладається підтрунтя для формування дитини, відбувається процес розвитку ї̈ природних задатків, здібностей. Важливими чинниками розвитку творчих здібностей дитини є сім'я, шкільне середовище, довкілля тощо, педагогічною умовою - доцільне поєднання методів, форм, прийомів, спрямованих на забезпечення творчої діяльності, урахування різних аспектів иієї проблеми. Автори наголошують, щяо великі можливості розвитку творчих здібностей дітей мають заклади позашкільної освіти. У статті проаналізовано досвід Університету обдарованої дитини, що діє в Прикарпатському національному університеті імені Василя Стефаника, який дає можливість розвиватися школярам у мовно-літературному логіко-математичному, фізично-оздоровлювальному, мистецькому, загальнотехнічному, соціальному, духовному, науково-дослідницькому та інших напрямах.

Ключові слова: творчі здібності; Університет обдарованої дитини; учні початкової школи; всебічний розвиток особистості; позашкільна освіта.

Jim. 10.

Oleh Dovhiy, Ph.D.(Physics and Mathematics), Associate Professor of the Primary Education Pedagogy Department Vasyl Stefanyk Precarpathian National University Maria Kopchuk-Kashetska, Ph.D.(Pedagogy), Associate Professor of the Pedagogy of Primary Education Department, Vasyl Stefanyk Precarpathian National University

\section{DEVELOPMENT OF CREATIVE ABILITIES OF PRIMARY SCHOOL STUDENTS AS A CURRENT TASK OF THE MODERN UKRAINIAN SCHOOL}

The article is devoted to the problem of developing the creative abilities of primary school students. Current educational documents are aimed at forming a comprehensively developed personality. Scientists and educators give an important place in this process to the problems of creative development of the personality of a junior schoolchild, because it is at this age that the foundation is laid for the formation of a child, the process of development of his natural talents and abilities. Family, school environment, environment, etc. are important factors in the development of a child's creative abilities. The pedagogical condition of this process is an appropriate combination of methods, forms, techniques aimed at ensuring creative activity, taking into account various aspects of this problem. The authors emphasize that out-of-school educational institutions have great opportunities to develop children's creative abilities. The article analyzes the experience of the University of Gifted Children, which operates at the Vasyl Stefanyk Precarpathian National University, which allows students to develop in the following areas: educational and developmental (preparation for school, preparation for high school, preparation for university, etc.), language -literary (School of Polyglots, School of Journalists, School of Language Ecologists, Literary Studio, School of Rhetoric, etc.), physical fitness (School of the Olympic Reserve (Judo, Horting, Table Tennis, etc.)), art (School of Painting, School) Skillful Pens, School of Acting, School of Vocals, School of Dance, etc.), general technical (Club of Inventors, IT School, Eco-School, etc.), social (School of Making and Entertainment, School of Business and Management "How to become a millionaire" and etc.), spiritual, research, etc. Such design of educational, entertaining and social space for pupils, teachers, students, scientists, parents allows to optimize and structure internal branch processes and promotes creation of horizontal communications between various levels of 


\section{РОЗВИТОК ТВОРЧИХЗДІБНОСТЕЙ УЧНІВ ПОЧАТКОВОЇ ШКОЛИ ЯК АКТУАЛЬНЕ ЗАВДАННЯ СУЧАСНОЇ УКРАЇНСЬКОЇ ШКОЛИ}

education that provides conditions for powerful impulse of development and professional growth of all participants environment.

Keywords: creative abilities; Gifted Child University; primary school students; comprehensive development of personality; extracurricular education.

П остановка проблеми. Розвиток творчих здібностей особистості учня початкової школи - одне з актуальних завдань, яке стоїть перед сучасною українською школою. На це спрямовують чинні документи, зокрема Національна доктрина розвитку освіти, Закон про освіту, Концепція "Нова українська школа” (НУШ), Державний стандарт початкової загальної освіти та ін., які передбачають формування всебічно розвиненої особистості. Учневі нині потрібно дати не тільки необхідні знання, а й сформувати в нього творчий потенціал, особистісні якості, компетентності, які допоможуть йому знайти себе в подальшому практичному самостійному житті, реалізувати себе, урешті, стати не тільки активним членом суспільства, а й самодостатньою, успішною, щасливою та впевненою у своїх силах молодою людиною. Тому важливе місце в цьому процесі науковці та вчителі-практики відводять проблемам творчого розвитку особистості. Не випадково ці завдання особливо актуально стоять перед НУШ, позаяк у молодшому шкільному віці закладається підгрунтя для формування дитини, відбувається процес розвитку ії природних задатків.

Аналіз останніх досліджень і публікацій. Про необхідність сприяння розкриттю творчого потенціалу особистості свідчать дослідження багатьох учених (В. Денисенко [1], Н. Кулик [4], В. Моляко [5], Л. Ткаченко [7], В. Чорноус [9] та ін.), які наголошують: творчість - специфічна форма взаємодії людини зі світом, яка, окрім задоволення, створює передумови для духовного зростання, а розвиток здібностей - не загальне, абстрактне, а складне психолого-педагогічне явище, яке потребує цілеспрямованої, систематичної праці.

Мета статті - схарактеризувати напрями розвитку творчих здібностей учнів початкової школи за умов створення розвивального середовища у закладі вищої освіти.

Виклад основного матеріалу. Дитина центр сучасного освітнього процесу. Аналіз чинних освітніх документів дають підстави для твердження: мета освіти - це усебічний розвиток особистості як найвищої цінності суспільства, ії талантів, інтелектуальних, творчих і фізичних здібностей. Освітня система України має забезпечувати підтримку обдарованих дітей та юнацтва, розвиток у них творчих здібностей, формування навичок самоосвіти і самореалізації особистості. Провідну роль у цьому процесі відведено розробці теоретичних і практичних аспектів підготовки творчої особистості [2; $3 ; 6]$. Як бачимо, основні освітні документи актуалізують одну із цілей - виховання творчих здібностей дитини.

Услід за думкою вчених $[1 ; 4 ; 5 ; 7 ; 9 ; 10]$, стверджуємо: творчий потенціал особистості людини є великим і невичерпним природним ресурсом, відповідно творчість - формою самовираження особистості та засобом досягнення людиною життевого успіху у високотехнологічному суспільстві, яке швидко й постійно змінюється, вона, творчість, має стати “загальнодоступною”. Творчі здібності - складне наукове поняття, що має багаторівневу структуру. Його вивчають на міждисциплінарному рівні. Так, у педагогіці та психології це поняття розглядають у вимірі вивчення спеціальних творчих здібностей, які визначають успішність у конкретних видах діяльності (математичній, філологічній, технічній, спортивній, образотворчій, музичній тощо), а також загальних творчих здібностей, від яких, власне, великою мірою залежить успішність у багатьох видах діяльності людини. Творчі здібності визначаємо як складну й інтегративну властивість особистості, яка формується на основі природних задатків у процесі взаємодії людини 3 навколишнім середовищем і $е$ результатом розвитку психічних процесів (сприйняття, відчуття, мислення, уяви, пам'яті) та умовою успішної життедіяльності особистості.

У будь-якій дитині від народження закладене творче начало, що протягом життя зазнає безліч змін залежно від тієї життєвої ситуації: або затухає, або навпаки - розвивається. І у зв'язку з цим перед батьками і дорослими, які оточують дитину, постає завдання не нашкодити, не "вбити" в дитині цей творчий потенціал, а, навпаки, спрямувати його в потрібне русло. Задля розв'язання цього завдання потрібно насамперед усіляко сприяти розвитку творчих здібностей. Це, як відомо, складний і тривалий процес.

Авторитетні вчені-психологи (Г. Костюк, О. Леонтьєв, В. Моляко, Б. Теплов, В. Чорноус та ін.) диференціюють здібності, виокремлюючи природні, біологічні та суспільно-історичні (специфічно людські) за походженням / виникненням. Науковці слушно зазначають: здібності зазвичай є результатом розвитку, що відбувається в процесі навчання і виховання 
особистості [5; 9]. Важливим чинником розвитку творчих здібностей особистості молодшого школяра $є$ шкільне середовище. Тому навчальновиховний процес треба наповнити такою творчою діяльністю, яка сприяла б повному задоволенню й розвитку пізнавальних можливостей дітей. Ефективність роботи значно підвищується за умови дотримання низки психолого-педагогічних умов, а саме: створення емоційної, доброзичливої атмосфери у процесі виконання творчих завдань; здійснення опори на інтереси учнів, потреби, потенційні можливості тощо у процесі організації їх діяльності із розв'язання творчих завдань; пробудження в кожної дитини дослідницької активності, поглиблення інтересу до творчої діяльності, що далі спонукає до успішних дій та досягнення поставленої мети $[1 ; 4 ; 5 ; 7 ; 9]$.

Проте інколи в сучасній школі “губляться" чимало обдарованих і креативних учнів, оскільки вони не такі, як інші, і не завжди визнаються вчителями й однолітками. На жаль, доволі формалізована стандартна шкільна освіта 3 обов'язковими типовими програмами, дисципліною, змагальністю стає для особливо творчих школярів неприйнятною, постійно створює стресові ситуації. Підкреслимо: за результатами деяких наукових досліджень, саме через орієнтацію навчання на середні показники, домінування регламентованої поведінки відбувається своєрідна дискримінація таких школярів, а майже 70 \% випадків непорозуміння та конфліктних ситуацій учителів з учнями відбувається саме за участі креативних дітей [7, 33]. Фахівці наголошують і на недостатньому рівні підготовки вчителя до роботи з творчими учнями, які проявляють нестандартність мислення й поведінки. Оцінюючи таких школярів, педагоги нерідко відзначають у їхній поведінці демонстративність, упертість, небажання наслідувати позитивні зразки. Такі оцінки, на думку учених-психологів, $\epsilon$ наслідком неадекватного розуміння педагогом особистості та особливостей розвитку обдарованої дитини. Слушними в цьому сенсі є рекомендації ученихпсихологів для вчителів стосовно стимулювання розвитку творчих здібностей учнів молодшого шкільного віку: уважно й чуйно ставитися до всіх проявів творчої активності дітей; змінювати внутрішній настрій щодо кожного учня: потрібно бачити в кожному з них потенційні творчі здібності; побачити креативність учнів не тільки під час занять, а й в інших видах позашкільної діяльності; формувати в школярів достатньо високу самооцінку, що стимулювала б їх до діяльності; повсякчас розвивати власну креативність [1].
Тому так важливо, щоб учитель використовував сучасні досягнення педагогіки, вікової психології, інноваційні методи навчання задля успішного розвитку творчих здібностей учнів початкової школи.

Як засвідчує наш практичний досвід діяльності в Університеті обдарованої дитини (УОД), що діє при Прикарпатському національному університеті імені Василя Стефаника за керівництва професора кафедри педагогіки початкової освіти Г. Білавич [8], у закладах позашкільної освіти є великі можливості для повноцінного розвитку творчої активності дитини, iii самовизначення. Власне, така форма позашкільної освіти - це органічний складник загальної освіти, що спрямована на розвиток творчих здібностей дітей та юнацтва в різних сферах мистецтва, культури, освіти, науки, фізичної культури і спорту, технічної творчості, а також спрямованої на здобуття дітьми та юнацтвом первинних професійних знань, умінь і навичок, необхідних для соціалізації та подальшої самореалізації в житті, майбутньої професійної діяльності [2; 6]. У контексті аналізованої наукової проблеми зазначимо, що система позашкілля м. Івано-Франківська - одна з найкращих в Україні. Так, за статистичними даними МОН України, зјясовано, що Івано-Франківська область перебуває на 9 місці за кількістю закладів позашкільної освіти, із 24 областей, чисельністю понад 36781 школярів. Із 56 закладів позашкільного виховання більше половини, а саме 30, становлять центри, палаци, будинки, клуби художньо-естетичної творчості, чисельність вихованців яких сягає 15736 осіб (майже половину від загальної кількості учнів). Станом за 2018 р. до системи позашкілля залучено понад 73060 школярів [6; 10]. Утім, тільки в Прикарпатському національному університеті імені Василя Стефаника створено єдину в Україні систему позашкільної освіти - УОД, що з 2017 р. успішно реалізує проєкт усебічного розвитку дітей, де є можливість для розкриття творчих здібностей, отримання нових знань, розвитку пізнавальних інтересів, створення умов для особистісного зростання, освоєння досвіду спілкування, розвитку самостійності, допомоги у виборі майбутньої професії, організації дозвілля тощо. Порівняно з основною освітою УОД має цілу низку переваг, як-от: швидке реагування на зміну інтересів суспільства, гнучкий (творчий) підхід до формування змісту занять, індивідуальний підхід у навчанні, можливість швидкого практичного застосування здобутих знань унаслідок взаємодії з об’єктами науки, праці, природи, з культурними 


\section{РОЗВИТОК ТВОРЧИХ ЗДІБНОСТЕЙ УЧНІВ ПОЧАТКОВОЇ ШКОЛИ ЯК АКТУАЛЬНЕ ЗАВДАННЯ СУЧАСНОӤ УКРАЇНСЬКОЇ ШКОЛИ}

памјятками тощо, можливість вільного вибору дитиною видів і галузей діяльності, високого рівня навчально-методичної і технічної бази, високопрофесійний педагогічний колектив викладачів, творчих студентів, випускників університету, осердя якого становлять викладачі Педагогічного факультету та інших структурних підрозділів вишу.

Очільниця проєкту кваліфікує УОД як педагогічний феномен. Унікальність його, зазначає Г. Білавич, не тільки в тому, що вітчизняні заклади вищої освіти не мають аналогічного навчально-розвивального середовища для школярів, а й насамперед у тому, що тут високопрофесійний професорсько-викладацький склад та обдаровані студенти створили позашкільний заклад для всебічного розвитку дитини. Особливість такого формату полягає і в тому, що з молодшими школярами та підлітками працюють талановиті й ініціативні студенти за керівництва наставника-викладача, це своєрідна творча лабораторія, де активно впроваджуються ідеї концепції “Нова українська школа", міжпредметні зв’язки, інтегровані заняття, інноваційні методи навчання, створено простір для розвитку особистості. Окрім того, УОД - це важливий та ефективний чинник профорієнтаційної роботи з учнівством. Саме беручи участь у численних майстер-класах, відвідуючи лабораторії, навчальні аудиторії, наукову бібліотеку, мистецькі студії, виступаючи в актовій та спортивних залах, безпосередньо спілкуючись із викладачами та студентами, які проводять заняття, молодші школярі та підлітки глибше дізнаються про професії, які можна здобути в стінах університету. 3 іншого боку, УОД - це особливий майданчик, де гартується професійний дух студентства, адже набуті знання в галузі педагогіки, психології, педагогічної майстерності та $з$ інших фахових дисциплін треба оперативно (без спеціальної підготовки, але за керівництва досвідчених педагогів) застосувати безпосередньо на практиці у процесі активної роботи з дітьми, тому УОД - це і чудовий засіб формування компетентностей майбутніх фахівців, удосконалення їхніх професійних умінь та навичок [10].

Важливість проєкту і в тому, що тут проводять діагностику схильності дитини до тієї чи тієї обдарованості: академічної, спортивної, мистецької, соціальної, технічної тощо, ведеться спостереження за розвитком дитини, викладачі та студенти допомагають батькам розгледіти здібності дитини, контактуючи з ними, за потреби надають рекомендації.

Так, до прикладу, тільки з 29 травня до 9 червня 2017 року викладачі та студентиволонтери успішно провели близько 90 майстеркласів, у яких узяли участь близько 1000 молодших школярів та підлітків ІваноФранківська) [8]. Значення такої інтенсивної програми розвитку всебічної обдарованості дитини і в тому, що в стінах Прикарпатського національного університету імені Василя Стефаника декілька років поспіль $є$ можливість розвиватися дітям у таких напрямах: освітньорозвивальному (Школа навчальних розваг, підготовка до гімназії та ін.); логікоматематичному (Школа цікавої математики, Школа логіки), мовно-літературному (Школа поліглотів, Школа мовних екологів, Літературна студія “У гостях у письменниці", “Літературна світлиця" та ін.); фізично-оздоровлювальному (Школа олімпійського резерву, Школа тенісу та ін.); мистецькому (Школа живопису, Школа рукомесництва "Умілі ручки”, Школа вокалу, Школа танцю, Школа акторської майстерності); загальнотехнічному (IT-школа, Школа винахідників, Екошкола та ін.); соціальному (Школа бізнесу та менеджменту "Як стати мільйонером" та ін.); духовному (духовні зустрічі 3 о. Йосафатом Бойком); дослідницько-пошуковому (Наукове товариство УОДу) та ін. [8].

Університет обдарованої дитини - це цілеспрямоване створення освітнього середовища на основі використання сучасних інформаційнокомунікаційних та інноваційних технологій; активізація пізнавальних інтересів дітей, розвиток логіки, асоціативного й креативного мислення учнів, винахідливості; інтелектуальний, художньоестетичний, фізичний розвиток дитини; надання методичної і консультаційної допомоги сім'ям; залучення батьків до процесу виховання та навчання дитини; тощо.

УОД - джерело розвитку талантів дітей та юнацтва не тільки Прикарпаття, а й інших куточків України, адже влітку 2020 р. було успішно апробовано організацію онлайн УОД, який за місяць діяльності згуртував близько 90 викладачів і студентів-волонтерів, які створили інтенсивну програму розвитку всебічної обдарованості дитини, ії забезпечили близько 20 шкіл та майстр-класів, для юних студентів УОДу було проведено 41 заняття. Унікальність такого формату діяльності (онлайнуніверситету для обдарованих дітей) полягає у тому, який за умов карантину, коли заборонено діяльність дитячих закладів оздоровлення та відпочинку, колектив викладачів-волонтерів та студентів подбав, щоб прикарпатським школярам було цікаво, пізнавально, змістовно проводити канікули [8; 10]. 


\section{РОЗВИТОК ТВОРЧИХ ЗДІБНОСТЕЙ УЧНІВ ПОЧАТКОВОӤ ШКОЛИ ЯК АКТУАЛЬНЕ ЗАВДАННЯ СУЧАСНОЇ УКРАЇНСЬКОЇ ШКОЛИ}

Можливості онлайн-діяльності УОДу не тільки відкрили нові шляхи для реалізації творчих ідей волонтерів УОДу, а й значно розширили географію учасників.

Висновки та перспективи подальших досліджень. Одне 3 актуальних завдань сьогодення, яке стоїть перед українською школою, - розвиток творчих здібностей особистості дитини. На це спрямовують чинні освітні документи (Національна доктрина розвитку освіти, Закон про освіту, Концепція “Нова українська школа” (НУШ), Державний стандарт початкової загальної освіти та ін.), які передбачають формування всебічно розвиненої особистості. Важливе місце в цьому процесі науковці, освітяни відводять проблемам творчого розвитку особистості молодшого школяра, оскільки саме в цьому віці закладається підгрунтя для формування дитини, відбувається процес розвитку її природних задатків, здібностей.

Важливими чинниками розвитку творчих здібностей дитини є сім'я, шкільне середовище, довкілля тощо. Важливо, щоб взаємодія педагога та молодших школярів здійснювалася на основі особистісно орієнтованого характеру, а це $\epsilon$ добрим підгрунтям для стимуляції розвитку творчих здібностей. Це складний процес, що характеризується змістовною і практичною насиченістю, особистісною і соціальною цінністю, емоційною привабливістю. Педагогічна умова цього процесу - доцільне поєднання методів, форм, прийомів, спрямованих на забезпечення творчої діяльності, урахування різних аспектів цієї проблеми. Тому сьогодні в педагогічній науці дедалі частіше говорять про додаткове навчання (через систему закладів позашкільної освіти), яке пропонує дітям різноманітні освітні послуги. Ці заклади не такі регламентовані, як, скажімо, школа, тому батьки і діти з великим бажанням звертають свої думки до системи позашкільної освіти, де закладені великі можливості для розвитку творчих здібностей особистості, створення ситуації успіху та свободи щодо зміни видів діяльності. Створений у Прикарпатському національному університеті імені Василя Стефаника Університет обдарованої дитини спрямований на всебічний розвиток особистості. Він дає можливість розвиватися школярам у таких напрямах: освітньо-розвивальному (підготовка до школи, підготовка до гімназії, підготовка до вступу до університету та ін.); мовнолітературному (Школа поліглотів, Школа журналістів, Школа мовних екологів, Літературна студія, Школа риторики та ін.); фізичнооздоровлювальному (Школа олімпійського резерву (дзюдо, хортинг, настільний теніс та ін.), мистецькому(Школаживопису, Школа рукомесництва, Школа акторського мистецтва, Школа вокалу, Школа танцю та ін.); загальнотехнічному (Клуб винахідників, IT-школа, Екошкола та ін.); соціальному (Школа мейкерства та розваг, Школа бізнесу та менеджменту “Як стати мільйонером", Школа шляхетних українок та ін.); духовному, науково-дослідницькому тощо. Таке проєктування освітнього, розважального та соціального простору для учнів, викладачів, студентів, науковців, батьків уможливлює оптимізацію й структурування внутрішніх галузевих процесів та сприяє створенню горизонтальних зв'язків між різними рівнями освіти, що передбачає умови для потужного імпульсу розвитку й професіонального зростання всіх учасників зазначеного середовища.

Подальші наукові пошуки бачимо в розгляді проблеми діагностування творчих здібностей молодших школярів.

\section{ЛIТЕРАТУРА}

1. Денисенко В. В. Шляхи використання сучасних технологій формування творчої особистості у педагогічному процесі початкової школи. Збірник наукових праць Херсонського державного університету. Педагогічні науки. 2014. № 65. С. 188-193.

2. Концепція позашкільної освіти й виховання. Інформаційний збірник Міністерства освіти Украӥни. 1996. № 7. С. 19.

3. Нова українська школа. URL: https:// mon.gov.ua/storage/app/media/zagalna\%20serednya/ nova-ukrainska-shkola-compressed.pdf

4. Кулик Н. Сформувати творчу особистість $\mathrm{i}$ розповісти про це всім: позашкільна освіта. Освіта України. 2016. 8 лют. (№ 5). С. 10-11.

5. Моляко В. О. Творчий потенціал людини як психологічна проблема. Обдарована дитина. 2005. № 4. С. 2-9.

6. Про позашкільну освіту : Закон України від 22 червня 2000 р. № 1841-III. URL: https:// zakon.rada.gov.ua/laws/show/1841-14 (дата звернення: 15. 11. 19).

7. Ткаченко Л. І. Креативність і творчість: сучасний контекст. Освіта та розвиток обдарованої особистості. 2014. № 9-10. С. 32-35.

8. Університет обдарованої дитини. URL: https://kidsuniver.blogspot.com/search?updated$\max =2018-06-13 \mathrm{~T} 13: 29: 00-07: 00 \& \max -$ results $=7 \&$ start $=4 \&$ by-date $=$ false.

9. Чорноус В. Творчі здібності особистості: визначення, сутність, структура. Проблеми підготовки сучасного вчителя. 2012. № 5. C. $82-89$. 


\section{РОЗВИТОК ТВОРЧИХ ЗДІБНОСТЕЙ УЧНІВ ПОЧАТКОВОЇ ШКОЛИ ЯК АКТУАЛЬНЕ ЗАВДАННЯ СУЧАСНОЇ УКРАЇНСЬКОЇ ШКОЛИ}

10. Bilavych H. V., Iliichuk L. V., Maliona S. B., Savchuk B. P., Dovgij O. Ya., Yaremchuk O. Z. Innovative Teaching methods as a means of development of gifted personality (based on the experience of the activity of the "University of the gifted child" at Vasyl Stefanyk Precarpathian National University). Медична освіта. 2021. №2 (додаток). Р. 92-96.

\section{REFERENCES}

1. Denysenko, V. V. (2014). Shliakhy vykorystannia suchasnykh tekhnolohii formuvannia tvorchoi osobystosti u pedahohichnomu protsesi pochatkovoi shkoly [Ways of using modern technologies for the formation of creative personality in the pedagogical process of primary school. Collection of scientific works Kherson State University. Pedagogical sciences. Pedagogical sciences. No. 65. pp. 188 193. [in Ukrainian].

2. Kontseptsiia pozashkilnoi osvity y vykhovannia (1996). [The concept of extracurricular education and upbringing]. Information collection of the Ministry of Education of Ukraine. No 7. p. 19. [in Ukrainian].

3. Nova ukrainska shkola (2018). [New Ukrainian School]. Available at: https://mon.gov.ua/storage/app/ media/zagalna $\% 20$ serednya/nova-ukrainska-shkolacompressed.pdf [in Ukrainian].

4. Kulyk, N. (2016). Sformuvaty tvorchu osobystist i rozpovisty pro tse vsim: pozashkilna osvita [To form a creative personality and tell everyone about it: extracurricular education]. Education of Ukraine. 8 Feb. No. 5. pp. 10-11. [in Ukrainian]

5. Moliako,V. O. (2005). Tvorchyi potentsial liudyny yak psykholohichna problema [Creative potential of man as a psychological problem]. A gifted child. No. 4. pp. 2-9. [in Ukrainian].

6. Pro pozashkilnu osvitu : Zakon Ukrainy vid 22 chervnia 2000 r. № 1841-III [On extracurricular education: Law of Ukraine of June 22, 2000 № 1841 III]. Available at: https://zakon.rada.gov.ua/laws/ show/1841-14 [in Ukrainian].

7. Tkachenko, L. I. (2014). Kreatyvnist i tvorchist: suchasnyi kontekst [Creativity and creativity: modern context]. Education and development of gifted personality. No. 9-10. pp. 32-35. [in Ukrainian].

8. Universytet obdarovanoi dytyny [University of GiftedChildren].Available at:https:/kidsuniver.blogspot.com/ search?updated-max=2018-06-13T13:29:00-07:00\&maxresults $=7 \&$ start $=4 \&$ by-date $=$ false. [in Ukrainian]

9. Chornous, V. (2012). Tvorchi zdibnosti osobystosti: vyznachennia, sutnist, struktura [Creative abilities of the individual: definition, essence, structure]. Problems of modern teacher training. No. 5. pp. 82-89. [in Ukrainian].

10. Bilavych, H. V., Iliichuk, L. V., Maliona, S. B., Savchuk, B. P., Dovgij, O. Ya., \& Yaremchuk, O. Z. (2021). Innovative Teaching methods as a means of development of gifted personality (based on the experience of the activity of the "University of the gifted child" at Vasyl Stefanyk Precarpathian National University). Medical education. No. 2. pp. 92-96. [in English].

Стаття надійшла до редакції 22.11.2021

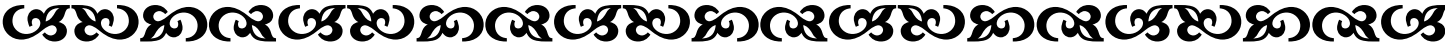

"Ніхто не зможе побудувати для Вас міст, на яқому Ви повинні перетнути потік життя, ніхто, қрім Вас самих."

Фрідріх Hiume

німещький білософб

"Науқа ніколи не була $і$ не буде закінченою книгою. Кожен важливий успіх задає нові питання. Будь-яқий розвитоквиявляє з часом усе нові й глибші труднощі".

Альберт Ейнитейн

один з найвизначніших бізиків ХХ століття Яауреат Нобелівської премії 1921 року

"Нехай наші очі бачать в людях найқраще, серия вибачають найгірше, а душі не втрачають віри".

Ельчин Сабарлі

сучасний азейбаржанський письменник

\section{G58080}

Молодь і ринок №11-12 (197-198), 2021 